Zelentsov D.G., Denysiuk O.R.

\title{
A METHOD FOR SOLVING PROBLEMS OF BENDING ROD OPTIMIZATION TAKING CORROSION INTO ACCOUNT
}

\author{
Ukrainian State University of Chemical Technology, Dnipro, Ukraine
}

\begin{abstract}
The article offers and justifies a method for solving a problem of optimal design of bent rods exposed to aggressive media. The problems of such class have special place among the problems of optimal design, which is explained by the fact that modeling corrosion deformation in structural elements requires solving not only the equations of solid mechanics, but also the system of differential equations describing the accumulation of geometric damage and including stress functions. The authors analyze existing approaches to solving these problem and problems of these approaches. On the basis of this analysis a fundamentally different approach to solving some problems of optimal design of bending rod elements that function in aggressive media is proposed, the statement of a problem, the numerical solution of which requires much less computational cost, and the result is the same as for the traditional problem statement, is proposed and justified. The authors consider a problem of vector optimization by two criteria: minimum area and perimeter of a cross-section at the time of exhaustion of the bearing capacity. The objective function includes the weight coefficient $\omega$, taking into account the influence of cross-sectional perimeter. A modified scheme for solving the optimization problem is created, which involves a module for one-dimensional optimization by parameter $\omega$. The proposed method is based on the assumption that there is only one value of the coefficient of perimeter influence, for which the solutions of problems in both traditional and new statements coincide. To compare these results correctly, it is necessary for a cross-section to be represented in both statements by a set of rectangular fragments both at an initial time and at a time corresponding to the limit state, so the model of corroding equivalent crosssection is used. A numerical illustration demonstrates almost complete coincidence of the solutions for both problem statements. At the same time utilization of developed method allows reducing the computational cost by several orders of magnitude compared to traditional methods for solving problems of this class.
\end{abstract}

Keywords: optimal design, aggressive medium, model of corroding cross-section, system of differential equations.

DOI: $10.32434 / 2521-6406-2019-5-1-15-22$

\section{Statement of the problem}

Problems of optimization of structures exposed to aggressive media have special place among the problems of optimal design. This is explained by the fact that the equations of solid mechanics of are not enough to calculate the constraint functions. The influence of aggressive media causes destruction of a surface layer of metal (corrosive wear) and, consequently, changes in initial geometric characteristics of structural elements. As noted in many works of Ukrainian and foreign researchers, mechanical stresses significantly accelerate the

(C) Zelentsov D.G., Denysiuk O.R., 2019 corrosion process [1-5]. In this case, a model of corrosion deformation of a structure is necessary for calculation of constraint functions. In its most general form, it consists of a system of differential equations (SDU) describing the accumulation of geometric damage and including stress functions, and a system of mechanical equations for calculation of the stressstrain state (SSS). The dimension of a SDU is determined by a number of parameters that allows a researcher to find a unique solution, which defines the geometric characteristics of a structure at any given time. When modeling the process of corrosive deformation in real structures, only the numerical 
solution of SDU is possible.

Thus, the problem of optimal design of corroding structures consists of two related tasks: to reduce computational costs and to ensure a required accuracy of the result. Previously, these tasks were accomplished by adapting numerical optimization methods and methods of solving systems of differential equations to the class of problems under consideration, including the creation of error control algorithms based on artificial neural networks (ANNs). This approach has partially solved the problems of accuracy and efficiency, but in general they still remain relevant.

This paper proposes a fundamentally different approach to solving some problems of optimal design of bending rod elements that function in aggressive media. The authors propose and justify the statement of a problem, the numerical solution of which requires much less computational cost, and the result is the same as for the traditional problem statement.

\section{Analysis of recent research and publications}

As noted above, the main ways to reduce computational costs in solving problems of optimal design of corroding structures were modifications of numerical methods of mathematical programming and methods for solving systems of differential equations. Considering the first approach, it is necessary to note the work [6] dedicated to the modification of the flexible tolerance method. The paper proposed to consider the integration step for SDU (and, consequently, its solution error) as a decreasing function of the iteration number in solving the problem of mathematical programming. This approach significantly reduced the computational cost, especially at the initial iterations, due to the relatively high error in the computation of constraint functions. However, it was impossible to predict a solution error since the influence of factors other than integration step value remained unexplored. These factors are the initial stress value, the parameters of an aggressive medium and the characteristics of cross-sections of rod elements (shape, area and perimeter). Later in $[7,8]$ information about the influence of these factors on the error of SDU solution was formalized using artificial neural networks. The use of ANNs made it possible to determine an integration step value for a SDU while solving the problem, depending on the required accuracy of a solution.

In the last decade, numerical-analytical methods have been used in the calculation of constraint functions [9], increasing efficiency due to a reasonable change in the integration step in the process of solving a SDU.
All of these modifications have improved the efficiency of computations, which allowed the researchers to solve a number of complex applied problems, but in general the problem of optimal design of corroding structures remains relevant.

A characteristic feature of bending rod elements is that corrosion leads to a change not only in size but also in shape of a section [9]. The reason is the uneven distribution of stress across the height of a section. As a result, firstly, the number of parameters that determine the geometric characteristics of a section at random moment of time increases, and, secondly, for a random section, it has not yet been possible to obtain user-friendly analytical dependences that allow a researcher to determine the durability of an element. In the study of such structures, the use of the above modifications of computational procedures is not possible.

The fact of the influence of cross-section perimeter of a bent corroding rod on its optimal parameters was described, for example, in [10]. In this paper a new problem statement, which makes it possible to determine the optimal parameters of a rod with rectangular cross-section, was also proposed.

\section{Formulation of the research objectives}

As an object of research in this article rod elements (beams) in conditions of pure bending intended for operation in aggressive media are considered. For certainty, we will consider the Ibeam. The weight optimization problem is formulated as follows: it is required to determine the dimensions of a beam cross-section so that its area is minimal and for a given time a beam retains its load-bearing capacity. In the form of a problem of nonlinear mathematical programming, this formulation under strength constraints has the form:

$$
\begin{gathered}
A(\bar{x}) \rightarrow \min ; \bar{x} \in X_{D} \\
X_{D}:\left\{\bar{x} \in E^{n} \mid g(\bar{x})=[\sigma]-\sigma\left(\bar{x}, t^{*}\right) \geq 0\right\} .
\end{gathered}
$$

Here $\mathrm{x}=\left[\mathrm{H}_{0} ; \mathrm{B}_{0} ; \mathrm{D}_{0} ; \mathrm{T}_{0}\right]^{\mathrm{T}}$ is the vector of variable parameters; $\mathrm{A}$ is the cross-sectional area of a rod element; $\sigma$ and $[\sigma]$ are the current and the limit values of stress; $t^{*}$ is the specified service life.

As a model of geometric damage accumulation, the following differential equation will be used [11,12]:

$$
\frac{\mathrm{d} \delta_{\mathrm{i}}}{\mathrm{dt}}=\mathrm{v}_{0} \cdot(1+\mathrm{k} \sigma) ;\left.\quad \delta\right|_{\mathrm{t}=0}=0,
$$

where $\delta_{\mathrm{i}}$ is the depth of corrosion damage (damage parameter); $\mathrm{v}_{0}$ is the corrosion rate in the absence of 
stress; $\mathrm{k}$ is the coefficient of stress influence on the rate of corrosion process; $t$ is time.

The possibility of using equation (2) in modeling the processes of corrosion deformation is justified in the monograph $[9,13]$.

The calculation of constraint functions (CF) involves the calculation of the stress state in a crosssection at a given time, taking into account the corrosion process occurring in it.

Models of corroding cross-sections under pure bending conditions are described in detail in [9]. Main provisions necessary to solve the problem are described below.

Two parameters are enough to determine the size and shape of a section at given time: $\delta_{1}$ and $\delta_{2}$ (Fig. 1).

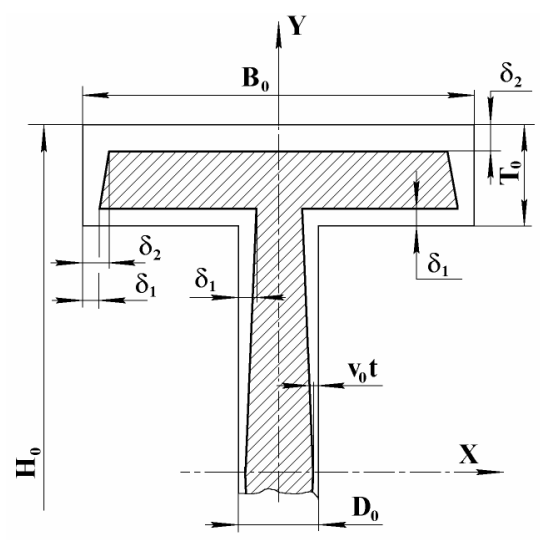

Fig. 1. I-beam cross-section

The system of differential equations for these parameters has a form:

$$
\begin{cases}\frac{\mathrm{d} \delta_{1}}{\mathrm{dt}}=\mathrm{v}_{0}\left(1+\mathrm{k} \sigma_{1}\right) ; & \delta_{1}(0)=0 \\ \frac{\mathrm{d} \delta_{2}}{\mathrm{dt}}=\mathrm{v}_{0}\left(1+\mathrm{k} \sigma_{2}\right) ; & \delta_{2}(0)=0\end{cases}
$$

Stresses $\sigma_{1}$ and $\sigma_{2}$ are calculated according to formulas:

$$
\begin{aligned}
& \sigma_{1}=\frac{\mathrm{M}\left(\mathrm{H}_{0}-2 \mathrm{~T}+2 \delta_{1}\right)}{2 \mathrm{I}} \\
& \sigma_{2}=\frac{\mathrm{M}\left(\mathrm{H}_{0}-2 \delta_{2}\right)}{2 \mathrm{I}}
\end{aligned}
$$

where a value of the cross-sectional moment of inertia is determined as follows:

$$
\mathrm{I}=\frac{1}{12}\left\{\begin{array}{l}
{\left[\left(\mathrm{H}_{0}-2 \delta_{2}\right)^{3}-\left(\mathrm{H}_{0}-2 \mathrm{~T}_{0}+2 \delta_{1}\right)^{3}\right] \times} \\
\times\left(\mathrm{B}_{0}-0,5 \mathrm{v}_{0} \mathrm{t}-1,5 \delta_{2}\right)+ \\
+\left(\mathrm{H}_{0}-2 \mathrm{~T}_{0}+2 \delta_{1}\right)^{3} \times \\
\times\left(\mathrm{D}_{0}-0,5 \mathrm{v}_{0} \mathrm{t}-1,5 \delta_{1}\right)
\end{array}\right\}
$$

Thus, the computation of constraint functions in the optimization problem involves solving numerically the system of differential equations (3) together with the equations (4) and (5). A scheme for solving the optimization problem is a two-circuit scheme (Fig. 2) where OF is a module for computation of objective function; $\mathrm{CF}$ is a module for computation of constraint function; PR is a module for recalculation of cross-sectional parameters; NLP is a module for solutions of the nonlinear programming problem.

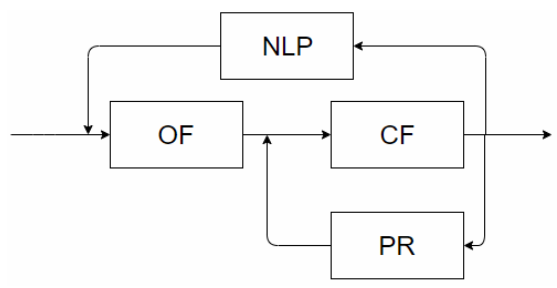

Fig. 2. Two-circuit scheme for solving the optimization problem

The presence of feedback significantly increases a computational cost of solving the optimization problem and sensitivity to errors in the calculation of a constraint function. Nevertheless, it is possible to obtain a strict solution of the optimization problem only in this way.

On the other hand, an alternative approach to solving optimization problems for corroding structures has been used for more than 20 years. It consists in finding an optimal solution for a neutral medium with subsequent restoration of a sacrificial metal layer [14] (Fig. 3).

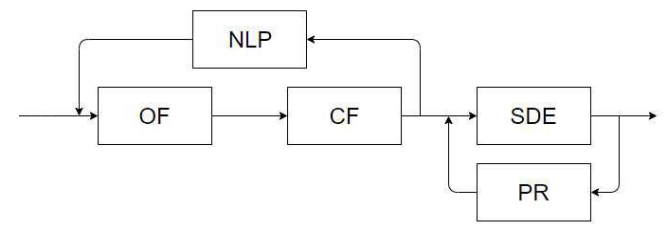

Fig. 3. Scheme for solving the optimization problem with separate sequential circuits 
Here SDU is a module for solving a system of differential equations.

Variable parameters in this case are the dimensions of a cross-section at the time of exhaustion of the bearing capacity: $\bar{x}=\left[\mathrm{H}_{t} ; \mathrm{B}_{t} ; \mathrm{D}_{\mathrm{t}} ; \mathrm{T}_{\mathrm{t}}\right]^{\mathrm{T}}$. With regard to the object of this study, a formulation of the problem in this approach is the following:

$$
\begin{array}{r}
\mathrm{A}(\overline{\mathrm{x}}) \rightarrow \min ; \overline{\mathrm{x}} \in \mathrm{X}_{\mathrm{D}} ; \\
\mathrm{X}_{\mathrm{D}}:\left\{\overline{\mathrm{x}} \in \mathrm{E}^{\mathrm{n}} \mid \mathrm{g}(\overline{\mathrm{x}})=[\sigma]-\sigma(\overline{\mathrm{x}}) \geq 0\right\} .
\end{array}
$$

In this case, the strength constraint can be used as a coupling equation, and formally the problem takes a form of an unconditional optimization problem with three variable parameters. The system of differential equations is solved only once. Despite the fact that the advantages of this approach are obvious from the point of view of computational costs, it is not a complete alternative to the traditional formulation of the problem for the following reasons.

1. In reality, the dimensions of an I-beam crosssection are determined by the structural constraints (the boundaries of variation of the variable parameters) and the coupling equation (the strength constraint), so they are not optimal in the conventional sense of the word. Since the constructive constraints are determined by a person who sets a task, the only solution of the problem (6) does not exist at all.

2. The problem statement (1) assumes that at the initial moment of time a cross-section is represented by rectangular fragments. Since the stress varies linearly in a height of a cross-section, at the moment of exhaustion of the bearing capacity it loses its initial form (Fig. 1). Obviously, when building a sacrificial layer of metal (solution of the system (3) when changing the sign in the right parts) on a crosssection, the dimensions of which will be determined from a solution of the problem (6), at the initial moment of time it won't also be represented by rectangular fragments. Therefore, it is not possible to make a correct comparison of results obtained by solving optimization problems in statements (1) and (6).

3. An optimal solution of the problem in the statement (1) is significantly influenced by the perimeter of a cross-section $\mathrm{P}$, which is implicitly included in the constraint function. The change in the cross-sectional area $\Delta \mathrm{A}$ due to corrosion will be determined by the formula

$$
\Delta A=v_{0} \int_{P} \int_{0}^{t^{*}}(1+k \sigma(P, t)) d P d t .
$$

At the same time, the statement (6) completely ignores this fact.

The objective of this work is to develop a method that will allow obtaining the same results as in the statement (1) at minimal computational cost required to solve a problem in the formulation (6).

\section{An outline of the main research material}

We consider a problem of vector optimization by two criteria: minimum area and perimeter of a cross-section at the time of exhaustion of the bearing capacity:

$$
\begin{gathered}
G(\bar{x})=\omega \frac{P(\bar{x})-P^{-}}{P^{+}-P^{-}}+ \\
+(1-\omega) \frac{A(\bar{x})-A^{-}}{A^{+}-A^{-}} \rightarrow \min ; \bar{x} \in X_{D} \\
X_{D}:\left\{\bar{x} \in E^{n} \mid g(\bar{x})=[\sigma]-\sigma(\bar{x}) \geq 0\right\}
\end{gathered}
$$

Here $\omega$ is the weight coefficient, taking into account the influence of cross-sectional perimeter $(\omega \in[0 ; 1]) ; \mathrm{P}^{-}, \mathrm{P}^{+}, \mathrm{A}^{-}, \mathrm{A}^{+}$is, respectively, the smallest and the largest of values that perimeter and area can take in a given range of variable parameter values.

Same as in the statement (6), found optimal cross-section sizes are increased by a value corresponding to the sacrificial metal layer. Therefore, there is a modified scheme for solving the optimization problem, presented in figure 4, where an additional block ODO is a module for onedimensional optimization by parameter $\omega$.

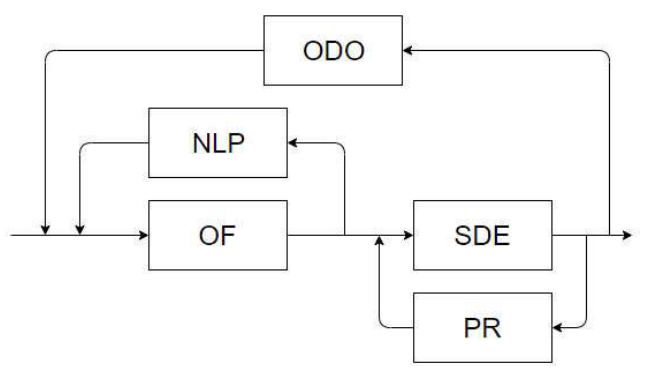

Fig. 4. A modified scheme for solving the optimization problem

The proposed method is based on the following assumption: there is only one value of the coefficient of perimeter influence, for which the solutions of problems in the statements (1) and (8) coincide. 
To confirm the validity of this thesis it is necessary to eliminate problems arising while solving the problem in the statement (6).

Problems of constructive constraints and ignoring the perimeter of a cross-section are eliminated by the problem statement itself.

To compare results correctly, it is necessary for a cross-section to be represented in both statements by a set of rectangular fragments both at an initial time and at a time corresponding to the limit state. In this case, it is proposed to use a model of corroding equivalent cross-section - a section that at any time retains its shape, and a value of its moment of inertia is equal to a moment of inertia of a cross-section with a changed shape. This is achieved by introducing a coefficient for stress averaging over a cross-section height. In particular, for the damage accumulation model (2), this coefficient is 0.75 . A detailed description for the model of corroding equivalent cross-section is given in [9]. Using this model, a system of differential equations describing the change in size of an I-beam cross-section (Fig. 5) takes the form:

$$
\left\{\begin{array}{l}
\frac{\mathrm{d} \delta_{1}}{\mathrm{dt}}=\mathrm{v}_{0}\left(1+\mathrm{k} \sigma_{1}\right) ; \delta_{1}(0)=0 ; \\
\frac{\mathrm{d} \delta_{2}}{\mathrm{dt}}=\mathrm{v}_{0}\left(1+\mathrm{k} \sigma_{2}\right) ; \delta_{2}(0)=0 ; \\
\frac{\mathrm{d} \delta_{1 \mathrm{eq}}}{\mathrm{dt}}=\mathrm{v}_{0}\left(1+0,75 \mathrm{k} \sigma_{1}\right) ; \delta_{1 \mathrm{eq}}(0)=0 ; \\
\frac{\mathrm{d} \delta_{2 \mathrm{eq}}}{\mathrm{dt}}=\mathrm{v}_{0}\left(1+0,5 \mathrm{k}\left(\sigma_{1}+\sigma_{2}\right)\right) ; \delta_{2 \mathrm{eq}}(0)=0 .
\end{array}\right.
$$

When the sacrificial metal layer is restored, signs on the right side of the system (9) are reversed.

The cross-sectional moment of inertia for this model is determined by the formula:

$$
\mathrm{I}_{\mathrm{eq}}=\frac{1}{12}\left\{\begin{array}{l}
{\left[\left(\mathrm{H}_{0}-2 \delta_{2}\right)^{3}-\left(\mathrm{H}_{0}-2 \mathrm{~T}_{0}+2 \delta_{1}\right)^{3}\right] \times} \\
\times\left(\mathrm{B}_{0}-2 \delta_{2 \mathrm{eq}}\right)+ \\
+\left(\mathrm{H}_{0}-2 \mathrm{~T}_{0}+2 \delta_{1}\right)^{3}\left(\mathrm{D}_{0}-2 \delta_{\text {leq }}\right)
\end{array}\right\} .
$$

Fig. 5. Equivalent I-beam cross-section

For a numerical illustration, a beam of I-section was considered, and its geometric dimensions varied in the intervals: $5.0 \leq \mathrm{H} \leq 10.0(\mathrm{~cm}), 1.0 \leq \mathrm{B} \leq 4.0(\mathrm{~cm})$,
$0.1 \leq \mathrm{D} \leq 2.5(\mathrm{~cm}), 1.0 \leq \mathrm{T} \leq 2.5(\mathrm{~cm})$. The value of the bending moment $\mathrm{M}=100 \mathrm{kN} \cdot \mathrm{cm}$, corrosion rate in the absence of stress $v_{0}=0.1 \mathrm{~cm} /$ year, the coefficient of stress influence on the corrosion rate, the ultimate stress $[\sigma]=240 \mathrm{MPa}$. The durability of the structure varied in the range from 1 to 5 years to evaluate the optimal solution with varying degrees of aggressiveness of a medium.

It is obvious that the comparison of results of solving problems (1) and (8)-(9) is possible only when methods of their solution guarantee a global extremum. Since the number of variable parameters is small, the brute force method was used in this paper. The parameters of computational procedures were chosen in such a way that maximum permissible errors in solution of the system of differential equations (9) and optimization problems themselves in both statements were the same. In particular, a spatial grid with the uniform distance between nodes equal to 0.01 of the length of the change interval for each variable parameter was used to solve the global optimization problem by the brute force method. The step for solving the SDE numerically was taken to be $h_{t}=0.002 t^{*}$.

The solution of the problem in the statement (1) was taken as a reference.

In particular, for $t^{*}=5.0$ years the following optimal solution for the initial time was obtained: $\bar{x}=[7,38 ; 2,1754 ; 1,2176 ; 2,3626]^{\mathrm{T}} ; \mathrm{A}=13.5117 \mathrm{~cm}^{2}$. At the time of destruction, the dimensions of the cross-section were the following: $\overline{\mathrm{x}}_{\mathrm{t}}=[6,0725 ; 0,8679 ; 0,1001 ; 1,1304]^{\mathrm{T}}$. The maximum stress value in the cross-section was $\sigma_{\mathrm{t}}=239.99 \mathrm{MPa}$. The analysis of the obtained solution leads to the conclusion that an optimal design is determined, among other factors, by a strength restriction and a lower limit for a structural restriction on the parameter D (Fig. 3). Similar conclusions follow from the analysis of solutions obtained for other values of $t^{*}$.

When solving the problem in the statement (8)(9), the number of variable parameters of the internal optimization problem was reduced to two due to the use of a coupling equation and taking into account the information obtained while solving the previous problem.

The results of solving the internal optimization problem are shown in table 1 for $t^{*}=5.0$ years.

The bottom row of the table shows the results of external optimization by parameter $\omega$. The internal optimization problem was solved by the method of parabolas. 
The discrepancy between the solution results on the value of cross-sectional area at the initial time was $0.32 \%$. This result can be considered quite satisfactory taking into account the fact that in the numerical implementation for both statements there were errors of the brute force method, the solution of systems of differential equations and, for the second formulation, the parabolas method used for external optimization.

Table 1

Optimal solutions for different values of parameter $\boldsymbol{\omega}$

\begin{tabular}{c|c|c|c|c|c}
\hline$\omega$ & $\mathrm{H}, \mathrm{cm}$ & $\mathrm{B}, \mathrm{cm}$ & $\mathrm{D}, \mathrm{cm}$ & $\mathrm{T}, \mathrm{cm}$ & $\mathrm{A}, \mathrm{cm}^{2}$ \\
\hline 0.200 & 7.75717 & 2.14737 & 1.22975 & 2.22379 & 13.62059 \\
0.220 & 7.62171 & 2.16506 & 1.22763 & 2.25665 & 13.58758 \\
0.240 & 7.50174 & 2.18154 & 1.22542 & 2.28755 & 13.56713 \\
0.260 & 7.39450 & 2.19697 & 1.22313 & 2.31682 & 13.55690 \\
0.280 & 7.29791 & 2.21151 & 1.22080 & 2.34471 & 13.55512 \\
0.300 & 7.21040 & 2.22522 & 1.21841 & 2.37145 & 13.56044 \\
\hline 0.275 & 7.32110 & 2.20796 & 1.22138 & 2.33787 & 13.55486 \\
\hline
\end{tabular}

When solving the problem in the statement (1) with the above parameters of the computational method, SDU (9) was solved numerically 103183209 times, while in the formulation (8)-(9) it was solved only 11 times.

In table 2 the results of solving the problem in two statements with different values of the parameter of medium aggressiveness $\mathrm{v}_{0} \mathrm{t}$ are shown. Here are the optimal values of the coefficient of perimeter influence $\omega$, the values of cross-sectional areas: $A_{1}$ and $\mathrm{A}_{2}$ obtained while solving problems in statements (1) and (8)-(9) respectively, and the values of discrepancy of the results.

Table 2

Optimal solutions for different values of parameter $v_{0} t$

\begin{tabular}{c|c|c|c|c}
\hline$v_{0} \mathrm{t}, \mathrm{cm}$ & $\omega$ & $\mathrm{A}_{1}, \mathrm{~cm}^{2}$ & $\mathrm{~A}_{2}, \mathrm{~cm}^{2}$ & $\varepsilon, \%$ \\
\hline 0.1 & 0.106 & 4.338 & 4.343 & 0.12 \\
\hline 0.2 & 0.169 & 6.665 & 6.674 & 0.14 \\
\hline 0.3 & 0.214 & 8.327 & 8.342 & 0.18 \\
\hline 0.4 & 0.248 & 11.196 & 11.226 & 0.27 \\
\hline 0.5 & 0.275 & 13.512 & 13.555 & 0.32 \\
\hline
\end{tabular}

These results confirm almost complete coincidence of the solutions for both problem statements.

\section{Conclusions}

A new method for solving a class of problems of optimal design of corroding structural elements is proposed and justified. It makes it possible to solve the problem of search for optimum parameters of a cross-section as a lower-dimension two-criterion problem of unconstrained optimization (the criteria are minimum area and perimeter of a cross-section). The solution of this problem is followed by the restoration of a sacrificial metal layer at a given value of the parameter $\omega$, which is the coefficient of perimeter influence (internal optimization), and onedimensional optimization of this parameter (external optimization). Analysis of the results of numerical experiments confirms the fact of reducing the computational cost by several orders of magnitude compared to traditional methods for solving problems of this class. Further increase in efficiency of the proposed method can be achieved, according to the authors, by approximating the dependence of the coefficient of perimeter influence on a degree of aggressiveness of a medium and a value of an applied load. In this case, there is no need to solve the problem of external optimization.

\section{REFERENCES}

1. Baia L., Jiang K., Gaoa L. The Influence and Mechanism of Residual Stress on the Corrosion Behavior of Welded Structures // Materials Research. - 2018. - Vol.21. - No. 5. - 10 p.

2. Ibrahim R.A. Handbook of Structural Life Assessment. - John Wiley \& Sons Ltd, 2017. - 1016 p.

3. Poursaee A. Corrosion of Ti-6Al-4V orthopaedic alloy under stress // Materialia. - 2019. - Vol.6. - 18 p.

4. Василенко О.Г. Оптимізація елементів фермових конструкцій з урахуванням спільної дії силових навантажень та агресивного середовища // Проблеми обчислювальної механіки і міцності конструкцій: зб. наук. праць. - Дніпропетровськ: Наука і освіта, 2008. - Вип.12. - С.20-33.

5. Алексеенко Б.Г. Метод дискретной оптимизации стержневых систем, взаимодействующих с агрессивными средами // Системні технології: зб.наук.праць. - Дніпропетровськ. - 2001. - № 5. - С.77-85.

6. Зеленцов Д.Г, Науменко Н.Ю. Адаптация метода скользящего допуска к задачам оптимизации корродирующих конструкций // Системні технології. Регіональний міжвузівський збірник наукових праць. - Дніпропетровськ, 2005. - Вип.2(37). - С.48-56.

7. Короткая Л.И. Использование нейронных сетей при численном решении некоторых систем дифференциальных уравнений // Восточно-европейский журнал передовых технологий. - 2011. - № 3/4(51). - С.24-27.

8. Радуль О.А. Оптимальне проектування кородуючих конструкцій з використанням штучних нейронних мереж // Промислове будівництво та інженерні споруди. - К.: ТОВ «Український інститут сталевих конструкцій ім. В.М. Шимановського», 2012. - № 1. - С.16-18.

9. Зеленцов Д.Г., Ляменко О.А., Науменко Н.Ю. Информационное обеспечение расчётов корродирующих объектов. 
Математические модели и концепция проектирования систем. - Днепропетровск: УГХТУ, 2012. - 264 с.

10. Радуль А.A. Нейросетевая идентификация двух схем решения задачи оптимизации корродирующих балок // Вісник ПБАДА. - 2012. - № 6. - С.18-23.

11. Долинский В.М. Изгиб тонких пластин, подверженных коррозионному износу // Динамика и прочность машин. - 1975. - № 21. - С.16-19.

12. Науменко Н.Ю., Ляшенко О.А. Математичні моделі процесу корозії в задачах будівельної механіки кородуючих конструкцій // Вопросы химии и химической технологии. 2010. - № 6. - С.144-147.

13. Філатов Г.В. Основи еволюційної теорії ідентифікації математичних моделей корозійного руйнування. Дніпропетровськ, УДХТУ. - 2010. - 191 с.

14. Василенко О.Г., Дзюба А.П. Алгоритм оптимального проектування кільцевих пластин за оцінкою кінцевого стану з урахуванням впливу агресивного середовища // Проблеми обчислювальної механіки і міцності конструкцій: зб.наук.праць. - Дніпропетровськ: Ліра, 2011. - Вип.16. C.79-85.

Received 28.05.2019

\section{МЕТОД РОЗВ'ЯЗАННЯ ЗАДАЧ ОПТИМІЗАЦІЇ ЗГИННИХ СТРИЖНІВ З УРАХУВАННЯМ КОРОЗІЙНОГО ЗНОСУ}

\section{Зеленцов Д.Г., Денисюк О.Р.}

У статті пропонується і обгрунтовується метод розв 'язання задачі оптимального проектування згинних стрижнів, що знаходяться під впливом агресивних середовищ. Задачі такого класу займають особливе місце серед задач оптимального проектування, що пояснюється тим, що моделювання корозійної деформації в елементах конструкиії вимагає розв 'язання не тільки рівнянь механіки твердого тіла, але і системи диференціальних рівнянь, що описують накопичення геометричних пошкоджень і включають в себе функиії напружень. Автори аналізують існуючі підходи до розв 'язання подібних задач і проблеми, що виникають при їх використанні. На основі виконаного аналізу запропоновано принципово інший підхід до розв 'язання деяких задач оптимального проектування згинних стрижневих елементів, що функціонують в агресивних середовищах, а також запропоновано і обгрунтовано постановку задачі, чисельний розв 'язок якої вимагає набагато менших обчислювальних витрат, а результат збігається з традиційною постановкою. Автори розглядають задачу векторної оптимізації за двома критеріями: мінімальної площі і периметра поперечного перерізу в момент вичерпання несучої здатності. Цільова функція включає в себе ваговий коефіцієнт $\omega$, що враховує вплив периметра поперечного перерізу. Створена модифікована схема розв 'язання задачі оптимізації, що включає модуль одновимірної оптимізації за параметром $\omega$. Запропонований спосіб заснований на припущенні, що існує тільки одне значення коефіцієнта впливу периметра, при якому розв'язки задачі як в традиційній, так $i$ в новій постановках збігаються. Для правильного порівняння цих результатів необхідно, щоб переріз було надано в обох постановках набором прямокутних фрагментів як в початковий момент часу, так і в момент, що відповідає граничному стану, тому використовується модель кородуючого еквівалентного перерізу. Чисельна ілюстрація демонструє майже повний збіг розв'язків для обох постановок задачі. У той же час, використання розробленого методу дозволяє знизити обчислювальні витрати на кілька порядків в порівнянні з традиційними методами розв'язання задач иього класу.

Ключові слова: оптимальне проектування, агресивне середовище, модель кородуючого перерізу, система диференціальних рівнянь.

\section{МЕТОД РЕШЕНИЯ ЗАДАЧ ОПТИМИЗАЦИИ ИЗГИБАЕМЫХ СТЕРЖНЕЙ С УЧЕТОМ КОРРОЗИОННОГО ИЗНОСА}

\section{Зеленцов Д.Г., Денисюк О.Р.}

В статье предлагается и обосновывается метод решения задачи оптимального проектирования изгибаемых стержней, подверженных воздействию агрессивных сред. Задачи такого класса занимают особое место среди задач оптимального проектирования, ито объясняется тем, что моделирование коррозионной деформации в элементах конструкции требует решения не только уравнений механики твердого тела, но и системы дифференииальных уравнений, описывающих накопление геометрических повреждений и включающих в себя функции напряжений. Авторы анализируют существующие подходы к решению подобных задач и возникающие при их использовании проблемы. На основе проведенного анализа предложен приниипиально иной подход к решению некоторых задач оптимального проектирования изгибаемых стержневых элементов, функционируюших в агрессивных средах, а также предложена и обоснована постановка задачи, численное решение которой требует гораздо меньших вычислительных затрат, а результат совпадает с традиционной постановкой. Авторы рассматривают задачу векторной оптимизации по двум критериям: минимальной площади и периметру поперечного сечения в момент исчерпания несущей способности. Целевая функиия включает в себя весовой коэффициент периметра поперечного сечения. Создана модифицированная схема решения задачи оптимизации, включающая модуль одномерной оптимизации по параметру основан на предположении, что существует только одно значение коэффициента влияния периметра, при котором решения задачи как в традиционной, так и в новой постановках совпадают. Для правильного сравнения этих результатов необходимо, чтобы сечение было представлено в обеих постановках набором прямоугольных фрагментов как в начальный момент времени, так и в момент, соответствующий предельному состоянию, поэтому используется модель корродирующего эквивалентного сечения. Численная иллюстрация демонстрирует почти полное совпадение решений для обеих постановок задачи. В то же время, использование разработанного метода позволяет снизить вычислительные затраты на несколько порядков по сравнению с традиционными методами решения задач этого класса.

Ключевые слова: оптимальное проектирование, агрессивная среда, модель корродирующего сечения, система дифференциальных уравнений. 


\section{A METHOD FOR SOLVING PROBLEMS OF BENDING ROD OPTIMIZATION TAKING CORROSION INTO ACCOUNT}

\author{
Zelentsov D.G., Denysiuk O.R. \\ Ukrainian State University of Chemical Technology, Dnipro, \\ Ukraine
}

The article offers and justifies a method for solving a problem of optimal design of bent rods exposed to aggressive media. The problems of such class have special place among the problems of optimal design, which is explained by the fact that modeling corrosion deformation in structural elements requires solving not only the equations of solid mechanics, but also the system of differential equations describing the accumulation of geometric damage and including stress functions. The authors analyze existing approaches to solving these problem and problems of these approaches. On the basis of this analysis a fundamentally different approach to solving some problems of optimal design of bending rod elements that function in aggressive media is proposed, the statement of a problem, the numerical solution of which requires much less computational cost, and the result is the same as for the traditional problem statement, is proposed and justified. The authors consider a problem of vector optimization by two criteria: minimum area and perimeter of a crosssection at the time of exhaustion of the bearing capacity. The objective function includes the weight coefficient $\omega$, taking into account the influence of cross-sectional perimeter. A modified scheme for solving the optimization problem is created, which involves a module for one-dimensional optimization by parameter $\omega$. The proposed method is based on the assumption that there is only one value of the coefficient of perimeter influence, for which the solutions of problems in both traditional and new statements coincide. To compare these results correctly, it is necessary for a cross-section to be represented in both statements by a set of rectangular fragments both at an initial time and at a time corresponding to the limit state, so the model of corroding equivalent cross-section is used. A numerical illustration demonstrates almost complete coincidence of the solutions for both problem statements. At the same time utilization of developed method allows reducing the computational cost by several orders of magnitude compared to traditional methods for solving problems of this class.

Keywords: optimal design, aggressive medium, model of corroding cross-section, system of differential equations.

\section{REFERENCES}

1. Baia L., Jiang K., Gaoa L. The Influence and Mechanism of Residual Stress on the Corrosion Behavior of Welded Structures. Materials Research, 2018, vol. 21, no. 5. Available at: http:/ /www.scielo.br/scielo.php?script $=$ sci_arttext\&pid $=$ S1516$14392018000500219 \& \operatorname{lng}=$ en\&nrm=iso.

2. Ibrahim R.A. Handbook of Structural Life Assessment. John Wiley \& Sons Ltd, 2017. 1016 p.

3. Poursaee A. Corrosion of Ti-6Al-4V orthopaedic alloy under stress. Materialia, 2019, vol. 6. Available at: https:// www.sciencedirect.com/science/article/pii/ S2589152919300675?via\%3Dihub

4. Vasylenko O.G. Optymizacija elementiv fermovyh konstrukcij z urahuvannjam spil'noi' dii' sylovyh navantazhen' ta agresyvnogo seredovyshha [Optimization of truss structural elements taking into account the joint action of loads and aggressive medium]. Problemy obchysljuval'noi' mehaniky i micnosti konstrukcij: zbirnyk naukovyh prac' [Problems of computational mechanics and durability of structures: a collection of scientific works], Dnipropetrovsk, Lira, 2008, no. 12, pp. 20-33.
5. Alekseyenko B.G. Metod diskretnoj optimizacii sterzhnevyh sistem, vzaimodejstvujushhih s agressivnymi sredami [Method of discrete optimization of rod systems interacting with aggressive media]. Systemni tehnologii': zbirnyk naukovyh prac' [System technologies: a collection of scientific works], 2001, no. 5, pp. 77-85.

6. Zelentsov D.G., Naumenko N.Yu. Adaptacija metoda skol'zjashhego dopuska $k$ zadacham optimizacii korrodirujushhih konstrukcij [Adaptation of the flexible tolerance method for problems of optimization of corroding structures]. Systemni tehnologii': zbirnyk naukovyh prac' [System technologies: a collection of scientific works], 2005, no. 2(37), pp. 48-56.

7. Korotkaya L.I. Ispol'zovanie nejronnyh setej pri chislennom reshenii nekotoryh sistem differencial'nyh uravnenij [Use of neural networks for solving numerically some systems of differential equations]. Vostochno-evropejskij zhurnal peredovyh tehnologij [Eastern-European Journal of Enterprise Technologies], 2011, no. $3 / 4(51)$, pp. $24-27$.

8. Radul O.A. Optymal'ne proektuvannja korodujuchyh konstrukcij $z$ vykorystannjam shtuchnyh nejronnyh merezh [Optimal design of corrosion structures using artificial neural networks] Promyslove budivnyctvo ta inzhenerni sporudy [Industrial building and engineering structures], 2012, no. 1, pp. 16-18.

9. Zelentsov D.G., Liashenko O.A., Naumenko N.Yu. Informatsionnoe obespechenie raschetov korrodiruyushchikh ob'ektov. Matematicheskie modeli i kontseptsiya proektirovaniya system [Information support for calculations of corrosive objects. Mathematical models and concept of systems design]. Dnepropetrovsk: Ukrainian State University of Chemical Technology Publ., 2012. 264 p. (in Russian). DOI: 10.32434/mono-1-ZDG-LOA-NNY

10. Radul A.A. Nejrosetevaja identifikacija dvuh shem reshenija zadachi optimizacii korrodirujushhih balok [Neural network identification of two schemes to solve the optimization problem of corroding beams]. Visnyk PDABA [Bulletin of PSACEA], 2012, no. 6 , pp. 18-23.

11. Dolinskiy V.M. Izgib tonkih plastin, podverzhennyh korrozionnomu iznosu [Bending of thin plates subject to corrosive wear]. Dinamika i prochnost' mashin [Dynamics and strength of machines], 1975, no. 21, pp. 16-19.

12. Naumenko N.Yu., Liashenko O.A. Matematychni modeli procesu korozii'v zadachah budivel'noi' mehaniky korodujuchyh konstrukcij [Mathematical models of corrosion process in problems of construction mechanics of corrosion structures]. Voprosy himii i himicheskoj tehnologii [Issues of Chemistry and Chemical Technology], 2010, no. 6, pp. 144-147.

13. Filatov G.V. Osnovy evoljucijnoi' teorii' identyfikacii' matematychnyh modelej korozijnogo rujnuvannja [Fundamentals of evolutionary theory for identification of mathematical models of corrosion destruction]. USUCT, Dnipropetrovsk, 2010. 191 p.

14. Vasylenko O.G., Dzyuba A.P. Algorytm optymal'nogo proektuvannja kil'cevyh plastyn za ocinkoju kincevogo stanu z urahuvannjam vplyvu agresyvnogo seredovyshha [Algorithm for optimal design of ring plates by estimating the finite state, taking into account the influence of an aggressive medium]. Problemy obchysljuval'noi' mehaniky i micnosti konstrukcij: zbirnyk naukovyh prac' [Problems of computational mechanics and durability of structures: a collection of scientific works], Dnipropetrovsk, Lira, 2011, no. 16, pp. 79-85. 